\author{
«ДОШКОЛЬНЫЙ ПОХОД» КАК ЭЛЕМЕНТ \\ КУЛЬТУРНО-ПРОСВЕТИТЕЛЬСКОЙ КАМПАНИИ \\ КОНЦА 1920 - НАЧАЛА 1930-Х ГГ.: ПО МАТЕРИАЛАМ \\ АВТОНОМНОЙ ОБЛАСТИ КОМИ (ЗЫРЯН)
}

В статье рассмотрены особенности феномена «Дошкольного похода» как части культурной революции в советской России. Охарактеризованы общие тенденции развития дошкольного воспитания. Основное внимание уделено особенностям проведения «Дошкольного похода» в Автономной области Коми (Зырян). Проанализированы проблемы становления и развития системы дошкольных учреждений, их финансирования, формирования материальной базы, подготовки кадров, организации питания, медицинского обслуживания и совершенствования методики работы с дошкольниками. Авторы указывают на способы привлечения населения к вопросам общественного дошкольного воспитания. Выявлено, что реализация «Дошкольного похода» сопровождалась пропагандой новой марксистско-ленинской идеологии. Идеологическая составляющая стала обязательным компонентом всех мероприятий по расширению системы дошкольных учреждений и развитию методики дошкольного образования. Исследователи считают, что реализация «Дошкольного похода» в Коми автономии, даже при наличии ряда недостатков, способствовала масштабным изменениям в системе воспитания малолетних детей, активизации участия женщин-работниц в общественной и производственной жизни региона. Установлено, что большую роль в проведении «Дошкольного похода» сыграли пионерские, комсомольские, профсоюзные и партийные организации. Развитие методики работы с дошкольниками авторы отмечают как положительное явление. Улучшение методической поддержки заключалось не только в практической помощи педагогам, но и в трансляции лучшего опыта в прессе. Показано, что для преодоления дефицита профессиональных кадров для дошкольных учреждений в Коми области не ограничивались рамками краткосрочных педагогических курсов и привлечением случайных работников. В 1931 г. было открыто дошкольное отделение Сыктывкарского педагогического техникума. В ходе «Дошкольного похода» в Автономной области Коми (Зырян) удалось не только открыть значительное количество новых дошкольных учреждений, разнообразить формы дошкольного воспитания в городах и сельской местности, но и побудить население пересмотреть свои взгляды на воспитание детей.

Ключевые слова: культурная революция, ликвидация неграмотности, дошкольное воспитание, «Дошкольный поход», детские сады, детские площадки, Автономная область Коми (Зырян).

DOI: $10.35634 / 2224-9443-2021-15-1-147-156$

С начала 1920-х гг. в советской России (а затем и в СССР) по мере преодоления тяжелых последствий Первой мировой и Гражданской войн нарастали масштабные преобразования. С одной стороны, они были обусловлены острой необходимостью сохранения и развития страны, в том числе - обеспечением ее безопасности, поскольку оставалась актуальной угроза внешнего вторжения. В этой связи необходимо было обеспечить быстрый экономический подъем на индустриальной основе, что могли реализовать только грамотные работники. С другой стороны, после Октябрьской революции 1917 г. коренным образом менялись все основы жизни об- 
щества: этот процесс был напрямую связан с внедрением новой - марксистской (коммунистической) - идеологии. Коммунистическая партия и советская власть осознавали важность быстрейшего поднятия уровня культуры и - в широком смысле - просвещения населения страны, прежде всего, рабочих. В рамках этих культурно-просветительских и идеологических изменений разворачивалась инициированная ВКП(б) культурная революция. Для ее реализации, по мысли идеологов, необходим был широкий спектр инициатив и действий со стороны не только государства и партии, но и комсомола, профсоюзов и других общественных организаций. Эта деятельность приобретала разнообразные формы; некоторые из них отмирали, другие инициировались.

Первоначально при реализации культурной революции, что вполне объяснимо, огромное значение придавалось ликвидации неграмотности. Вероятно, поэтому рассмотрение проблем обозначенного феномена в нашей научной литературе во многом сводилось к исследованию данного аспекта. Подобный подход отчетливо проявился и в региональных трудах, например, по истории Коми АССР [История... 1981, 264-270]. Да и в постсоветских публикациях он явственно повторялся [Бабинцева, 112-132; Афанасова, Создание ... 2016, 62-69; Васильева, Воронцов, 270-285], хотя в обобщающих работах по истории Республики Коми значительно увеличилось количество привлекаемых источников, и расширилась характеристика процесса становления национальной школы [История... 2011, 341-352]. В подобных общих и региональных трудах, по сути, не учитывалось, что постепенно внедрялись все новые и новые подходы к работе с населением [Афанасова, Формирование ... 2016, 64-69; Егоров, Лыков, Волобуева, 11-32; Мартынчук, 43-49]. Так, в конце 1920-х гг. в стране получили развитие формы деятельности, связанные с понятиями «поход», «эстафета» и т. п. Однако их внедрение, реализация и значение не получили должного освещения в научных трудах и не нашли отражения даже в местных энциклопедических изданиях [Город... 2010, 3-408; Республика... 1997, т. 1, 3-472; т. 2, 3-576; т. 3, 3-400]. В лучшем случае они рассматривались исключительно как «форма ликвидации неграмотности» [Глущенко, 246-282]. На наш взгляд, эти новые формы культурнопросветительской кампании нуждаются в дополнительном осмыслении.

Одной из таких форм являлся «Дошкольный поход», оценка результативности которого на территории Автономной области Коми (Зырян) и предлагается в данной статье. Отметим, что проблемы «Дошкольного похода» не исследованы в исторических трудах. Имеются лишь отдельные работы ряда идеологов культурной революции, в которых содержатся только теоретические обоснования и программные установки разворачивания «Дошкольного похода», но отсутствуют данные о его реализации [Крупская, т. 6-9; Луначарский, 10-13; Луначарский, Скрыпник, 3-163].

Анализ «Дошкольного похода» предпринят авторами с учетом концепции «центр - периферия», т. е. в границах исследования взаимоотношений центральной и местной власти. Авторы подразумевают, что в роли «центра» могли выступать как столичные органы власти, так и центральные учреждения власти Северного края или Коми автономии, хотя часто встречалось их сочетание.

Для раскрытия темы привлекаются неопубликованные источники, обнаруженные в Национальном архиве Республики Коми. Они содержат нормативные и делопроизводственные документы: запросы и распоряжения органов власти и общественных организаций, отчеты, предложения по различным вопросам проводимых мероприятий и другие данные. Выявленные документы обладают высокой степенью объективности и позволяют оценить результаты «Дошкольного похода», отобразить процесс принятия решений по открытию детских учреждений, их финансированию, обеспечению кадрами, учебными пособиями, продуктами питания, новыми педагогическими методиками, а также охарактеризовать другие аспекты.

По мере достижения успехов в преодолении неграмотности становилось понятно, что необходимо выходить за эти узкие рамки и решать новые проблемы, которые имели отношение к культурной революции: во время первой пятилетки начиналась эпоха ускоренной индустриализации. В 1928 г. в СССР по инициативе комсомола был развернут так называемый культурный поход. В рамках ликвидации неграмотности предполагалось дополнять меры «против гря- 
зи и пьянства», «начав борьбу против всего ... бескультурья» [Крупская, т. 9, 342]. Через год был объявлен второй этап культурного похода, когда (уже без увязки с ликвидацией неграмотности) не только декларировалось усиление борьбы «с обывательскими нравами, мещанскими обычаями и другими пережитками старого быта», но и провозглашался «основной упор ... на борьбу за материальные основы нового быта» [Крупская, т. 9, 394].

В дополнение к реализации мероприятий второго этапа культурного похода в 1929 г. комсомол Москвы инициировал и начал осуществлять «Дошкольный поход». Н. К. Крупская, поддерживая начинания молодежи, отмечала, что в мероприятие необходимо вовлечь «всех друзей детей, взрослых и молодежь, членов партии, членов профсоюзов, учителей, врачей, учащихся, самих работниц и крестьянок, взяться за создание детсадов, детских комнат при фабриках, в жактах, в селах» [Крупская, т. 6, 100]. В рамках новой кампании предполагалось решить и еще одну важную задачу - сократить дефицит учреждений, разнообразить меры дошкольного воспитания и по возможности расширить сеть дошкольных организаций. Все это, в конечном итоге, было направлено на увеличение численности привлекаемых на производство работников (работниц, прежде всего) за счет освобождения от присмотра за детьми. Следует учитывать, что в конце 1920-х гг. государственные детские учреждения в советской России посещали только $2,5 \%$ детей дошкольного возраста; этого было крайне недостаточно [НАРК. Ф. Р-148. Оп. 1. Д. 474. Л. 139]. С другой стороны, в стране существовал огромный дефицит средств. Поэтому при минимальных затратах бюджета участники движения должны были обеспечить дошкольными учреждениями всех детей «трудящегося населения».

Реализуя «Дошкольный поход», комсомольцы организовывали субботники, создавали поощрительные фонды для финансирования учреждений, работали с населением. Студенты дошкольных отделений высших педагогических учебных заведений во время летних практик выезжали в отдаленные регионы страны с целью пропаганды идей общественного дошкольного воспитания и для непосредственной организации учреждений для малолетних детей. Для популяризации этого мероприятия на Выставке достижений народного хозяйства в Москве был создан павильон «Сельский детский сад». Хронике «похода» уделялось место в журнале «Дошкольное воспитание». Позже последовал «Дошкольный поход на село», целенаправленно пропагандировавший внедрение учреждений для мальщей в деревне. Детские организачии должны были искоренить деревенскую запуганность, «темноту», суеверия крестьянских семей и способствовать привлечению трудоспособных родителей к общественной работе. По истечении года «Дошкольный поход» по всей стране дал свои первые результаты: значительно «увеличилось количество учреждений, достигая при этом 500, 1000 и более высокого процента. В числе передовиков были западные области России, г. Саратов и г. Москва» [НАРК. Ф. Р-148. Оп. 1. Д. 474. Л. 55]. Наряду с этим «Дошкольный поход» «втянул в свою организацию работоспособное население и общественность».

Начало «Дошкольного похода» в Северном крае было запланировано на конец 1920-х - начало 1930-х гг. В Коми области, входившей в состав Северного края, в 1929 г. общественным дошкольным воспитанием был охвачен лишь 1\% дошколят [НАРК. Ф. Р-148. Оп. 1. Д. 474. Л. 135], поэтому создание новых учреждений для ребят являлось необходимой мерой.

Основную цель похода активисты видели в воспитании новой смены и ликвидации беспризорности дошколят. Общественники провозгласили лозунги: «Ни одного дома без уголка детей!», «Каждая работница должна быть знакома, как воспитывать детей!» [НАРК. Ф. Р-148. Оп. 1. Д. 474. Л. 128]. Поставлена задача открыть к началу 1931 г. при каждой фабрике, каждом лесозаводе и колхозе в Коми АО дошкольное учреждение: было запланировано создание 52 таких учреждений [НАРК. Ф. Р-148. Оп. 1. Д. 562. Л. 142].

Воплощая в жизнь идеи «Дошкольного похода», важно было решить ряд задач: организовать общее руководство мероприятием, изыскать средства для открытия дошкольных учреждений, подобрать помещения, подготовить кадры, упорядочить питание и медицинское обслуживание детей, проводить воспитательную работу с дошкольниками. Работа по реализации мероприятий «Дошкольного похода» на Севере не отличалась оригинальностью. В основном ее формы копировались с центральных районов в русле общих российских тенденций. Предлага- 
лось повысить цены на «кинобилеты», проводить платные лекции, поощрять вовлечение родителей в кооперацию. Кроме того, были организованы курсы по дошкольному воспитанию, инициировано шефство над новыми детсадами [НАРК. Ф. Р-148. Оп. 1. Д. 562. Л. 128].

Немало надежд возлагалось на пионеров Севера. Они получали «боевые задания» [НАРК. Ф. Р-148. Оп. 1. Д. 474. Л. 135]: например, написать 5000 лозунгов о дошкольном походе, провести митинги и беседы о пользе дошкольных учреждений. Было запланировано широкое освещение «Дошкольного похода» в региональном журнале «Организуйте детвору» [НАРК. Ф. Р-148. Оп. 1. Д. 474. Л. 91]. Всю подготовительную работу следовало провести до 1 октября 1929 г. В качестве одного из методических материалов была рекомендована статья «За здоровую смену», опубликованная в «Правде Севера» 5 сентября 1929 г. [НАРК. Ф. Р-148. Оп. 1. Д. 474. Л. 101]. Подготовительный план предполагал выявление числа детей дошкольного возраста по районам и крупным сельскохозяйственным предприятиям.

Общее руководство воспитательными заведениями после создания Коми автономии осуществлял Областной отдел народного образования (далее - ОБОНО). В рамках этого отдела действовал дошкольный сектор, при котором в 1929 г. был создан «штаб» «Дошкольного похода». Его руководителем стала Колерова (инициалы установить не удалось) [НАРК. Ф. Р-148. Оп. 1. Д. 562. Л. 123]. Аналитическая оценка состояния дошкольного воспитания начинает осуществляться с февраля 1931 г., когда появилась должность инспектора по данному направлению [НАРК. Ф. Р-148. Оп. 1. Д. 562. Л. 79]. В его обязанности входил учет количества детских садов и площадок в области, «охвата» ими детей по районам и предприятиям, анализ воспитательной работы в дошкольных учреждениях.

Планируя открытие детских садов, сотрудники ОБОНО столкнулись с проблемами финансирования проекта. Для открытия дошкольных учреждений только в колхозах и совхозах Коми автономии было необходимо изыскать 12040 руб. Помимо этого, только по трехмесячной смете на заработную плату педагогам всех 52 детских садов региона требовалось 11340 руб. (в среднем -72,6 руб. в месяц на один детский сад) [НАРК. Ф. Р-148. Оп. 1. Д. 474. Л. 142]. Дополнительных денежных субсидий в области не предполагалось, и даже ожидаемые из центра дотации всего в 700 руб. так и не поступили. Поэтому ОБОНО вынужден был обратиться к местным властям, профсоюзам, общественным и профессиональным организациям за субсидированием. Так, в 1930 г. областная детская комиссия выделила на эти нужды 1000 руб. [НАРК. Ф. Р-148. Оп. 1. Д. 474. Л. 62], столько же - областной профсоюзный комитет культуры [НАРК. Ф. Р-148. Оп. 1. Д. 474. Л. 48]. Профсоюз политпросветработников предложил собрать 250 р. «за счет надбавки цен на кинобилеты». Руководство Визингского района смогло выделить лишь 300 руб., в Ижемском районе изыскали 1700 руб., Удорском - 1000 руб., Усть-Куломском - 870 руб. [НАРК. Ф. Р-148. Оп. 1. Д. 474. Л. 75].

Отсутствие государственного финансирования срывало «Дошкольный поход». В Сыктывкаре, объявленном «районом сплошного дошкольного воспитания», за 1930 г. был открыт всего один детский сад. В Усть-Вымском, Визингском, Усть-Куломском районах общественность (профсоюзные и комсомольские организации) не поддержала идею создания новых дошкольных учреждений. Активисты Ижмы, несмотря на собранные деньги, так и не открыли ни одного детсада. Они смогли организовать лишь одну детскую площадку. Усть-Цилемские общественники, помимо открытия дошкольных учреждений, настойчиво поднимали вопрос об их снабжении материалами и пособиями, в то время как жители Сторожевска выражали сомнение в целесообразности «Дошкольного похода» [НАРК. Ф. Р-148. Оп. 1. Д. 474. Л. 75]. Таким образом, проблемы были не только финансовые, но и связанные с позицией жителей региона и ряда коллективных объединений, не осознавших важности общественного воспитания малолетних детей и не желавших тратить средства и усилия на создание дошкольных учреждений.

Несмотря на эти обстоятельства, первая годовщина «Дошкольного похода» в АО Коми отмечалась торжественными собраниями с участием родителей, педагогов и представителей общественности. Мероприятия сопровождались детскими демонстрациями, карнавалами, концертами художественной самодеятельности. Однако эти торжества явно диссонировали с достижениями «Дошкольного похода». С одной стороны, количество детских садов в Коми ав- 
тономии действительно увеличилось с 12 в 1929 г. до 19 в 1930 г. (на 58,3\%). Одновременно и количество детских площадок выросло с 12 до 56 (на 466,7\%) [НАРК. Ф. Р-148. Оп. 1. Д. 474. Л. 172]. С другой стороны, из проживающих в области 25450 детей до семи лет немногим более тысячи (всего 4\%) детей посещали детские сады [НАРК. Ф. Р-148. Оп. 1. Д. 474. Л. 216]. Впрочем, подобная картина наблюдалась и в других автономиях РСФСР, где «Дошкольный поход» поначалу развивался не так успешно и масштабно, как в столице или в ряде крупных промышленных центров.

В течение следующего 1931-го г. в рамках «Дошкольного похода» в Коми области количество стационарных детских садов увеличилось до 22 , и их посещало уже $6,6 \%$ детей до 7 лет (свыше 1,6 тыс.). При этом резервы для обустройства большого количества новых детских площадок, вероятно, были исчерпаны. Число детских площадок за год выросло с 56 до 65 (на 16,1 \%). Руководители области и организаторы «Дошкольного похода» поставили задачу «охватить 3000 дошкольников детскими садами, 9000 - площадками» [НАРК. Ф. Р-148. Оп. 1. Д. 474. Л. 52]. Дошкольные учреждения предписано было создавать не только в рабочих поселках и коммунах, но и в сельскохозяйственных артелях, среди «неорганизованного» населения и служащих. Организация заведений для малышей должна была стать одной из форм социалистического соревнования «за количественные и качественные показатели работы» [НАРК. Ф. Р-148. Оп. 1. Д. 474. Л. 240].

Рост числа дошкольных учреждений в Коми области все более тормозил дефицит помещений для них. О возведении специализированных зданий речи не шло. Все подходящие площади, в том числе в клубах и школах, арендовались или изымались для обустройства детских садов «нормального и примитивного типа» и детских площадок. Во всех жилых домах, имеющих 6-10 квартир, начали выделять помещения под детские комнаты. Возле строящихся 4-5 жилых объектов рекомендовалось планировать возведение специальных зданий или этажей для размещения детских садов. В целом 3-4\% всей строившейся в Коми автономии площади должно было отводиться под дошкольные учреждения.

Не менее остро стоял кадровый вопрос. Увеличение количества дошкольных учреждений требовало все большего числа специалистов для работы с детьми, прежде всего - воспитателей [НАРК. Ф. Р-148. Оп. 1. Д. 672. Л. 2]. Для разрешения проблемы Северный краевой «штаб» организовал комиссию, в которую включили представителей ВЛКСМ, Архангельского и Вологодского педагогических техникумов, и редакции газеты «Правда Севера» [НАРК. Ф. Р-148. Оп. 1. Д. 474. Л. 132]. Одним из способов разрешения проблемы нехватки кадров стала попытка пригласить на работу в Северный край, прежде всего в качестве заведующих и руководителей дошкольных учреждений, педагогических работников из Москвы и Ленинграда. Правда, все усилия оказались тщетны, и «из столиц», в частности, в Коми АО никто не приехал [НАРК. Ф. Р-148. Оп. 1. Д. 562. Л. 278].

В Коми области еще с 1926 г. периодически организовывали краткосрочные курсы, куда могли записаться все желающие девушки из столицы автономии [НАРК. Ф. Р-148. Оп. 1. Д. 212. Л. 25]. На этих «практикумах» в течение двух месяцев готовили руководителей дошкольных учреждений. При обучении акцент был сделан на практическую составляющую работы будущих специалистов. Обучение носило прикладной характер [НАРК. Ф. Р-148. Оп. 1. Д. 672. Л. 298]: в течение пятидневной трудовой недели два дня отводилось на освоение теоретических вопросов и три дня - на работу в дошкольных учреждениях. В ходе теоретических занятий «практикантки» знакомились с основными целями и задачами советской системы народного образования, принципами и методами работы в дошкольных учреждениях, такими как физическое воспитание, труд, игра, связь с окружающим миром, грамота и счет, изобразительное искусство, музыка, природоведение, коммунистическое и антирелигиозное воспитание. На практике обучающиеся занимались вопросами открытия детсадов или «очагов», подбора помещений, их оборудования, а также хозяйственной работой. Будущие педагоги учились формировать бюджет, планировать и учитывать свою работу.

Подобные курсы не могли в полной мере решить существующую проблему нехватки кадров. Для стабилизации ситуации с обеспечением детских учреждений работниками Северный краевой «штаб» «Дошкольного похода» рекомендовал организовать шестимесячные кур- 
сы по подготовке воспитателей, ввести обучающую практику при детских садах, кружки по дошкольному воспитанию при школах повышенного уровня и при избах-читальнях, открыть дошкольное отделение в педагогическом техникуме. Предложения были приняты, и в 1931 г. в шести районах Коми АО началась подготовка работников на этих полугодовых курсах.

Но главный шаг на пути преодоления недостатка кадров и для подготовки более профессиональных работников дошкольных учреждений был предпринят в декабре 1931 г.: в Сыктывкарском педагогическом техникуме открыли дошкольное отделение [НАРК. Ф. 1538. Оп. 1. Д. 1. Л. 249]. Изначально специальной приемной кампании не проводилось: для обучения на новое отделение по желанию была переведена необходимая часть студентов школьного отделения [НАРК. Ф. 1538. Оп. 1. Д. 1. Л. 38]. Во время обучения в педагогическом техникуме помимо теоретической подготовки (педагогики, психологии, анатомии, методики работы с детьми) много времени уделялось производственной практике, площадками для которой выступали детские сады Сыктывкара (до 1931 г. - Усть-Сысольска). Студенты проводили занятия, в программу которых входило обучение детей основам режима дня: утренняя зарядка, прием пищи, игры, самостоятельная деятельность детей. Также студенты осуществляли идейноагитационную пропаганду среди родителей [НАРК. Ф. 1538. Оп. 1. Д. 1. Л. 70].

Организация питания и медицинское сопровождение детей являлись обязательными условиями полноценной деятельности дошкольных учреждений. Специально построенных для детских садов зданий в Коми автономии еще не было, и для приема пищи рекомендовалось создавать детские столовые или отделения при столовых для взрослых, либо выделять в них особое время для питания детей. В колхозах предлагалось открывать детские кухни. Однако соблюдать нормативы по организации питания было очень сложно еще и из-за дефицита продуктов и - в случае приобретения - из-за трудностей с их доставкой в населенные пункты. Для решения проблемы предлагалось взаимодействовать с кооперативами и народным комиссариатом продовольствия. Эти действия предлагалось сочетать с созданием платных групп или организацией кормления детей за счет родителей. Затраты предполагались из расчета примерно по 20 коп. в день на ребенка [НАРК. Ф. Р-148. Оп. 1. Д. 562. Л. 165].

Инициаторы и активисты «Дошкольного похода» учитывали и то обстоятельство, что в семьях не всегда соблюдалось правильное питание детей. Для преодоления родительской неграмотности в отношении кормления детей педагоги и врачи проводили беседы с матерями и достаточно широко использовали наглядность: плакаты для уличной агитации, специальные информационные стенды (стенгазеты); этой теме посвящались заметки в газетах; использовались и другие формы работы с населением.

Изначально медицинское обслуживание детских учреждений в сельской местности и рабочих районах возложили на имеющихся там врачей и фельдшеров [Котов, Пилипенко, Деятельность ... 2010, 173-181]. Городские детсады и площадки патронировали школьные врачи и медицинские сестры запаса, прошедшие двухнедельные курсы (семинары). После открытия в 1930 г. Сыктывкарского медицинского техникума к этой работе активно подключались и его студенты. В результате, начиная с 1930 г. все детские учреждения г. Сыктывкара были охвачены врачебным и санитарным надзором. Медицинские работники помогали подбирать помещения, проводили профилактические осмотры и диспансеризацию [Котов, Пилипенко, Здравоохранение ... 2011, 16-136]. Особое внимание уделялось лечению и профилактике кожно-паразитарных и глистных заболеваний [НАРК. Ф. Р-148. Оп. 1. Д. 474. Л. 169]. Достаточно оперативно все дошкольные учреждения Коми АО были обеспечены аптечками [НАРК. Ф. Р-148. Оп. 1. Д. 474. Л. 161].

Воспитательная работа в дошкольных организациях Коми области строилась на принципах, сформулированных в концепции Единой трудовой школы. Педагоги проводили с детьми занятия по развитию речи, математике, эстетическому воспитанию. Вся работа с дошкольниками была выдержана в русле марксистко-ленинской идеологии, которая являлась обязательным компонентом любого занятия.

Для эффективной работы с детьми необходимо было использовать наглядные пособия, игрушки и другой вспомогательный материал. Однако такой материал отсутствовал, так как нигде не производился специально. Поэтому в Коми автономии организаторы и активисты 
«Дошкольного похода» предлагали для создания вспомогательных дидактических материалов использовать местные ресурсы: мастерские, технические кружки в клубах, студии и другие детские организации. Также к изготовлению игрушек и пособий для дошкольных учреждений привлекались родители и кустари. С этой же целью активизировалась и работа среди пионеров, которых нацеливали «на сбор бросового материала» и создание из него игрушек и других пособий. Были организованы и другие формы проведения данного мероприятия. Так, пионеры г. Усть-Сысольска (Сыктывкара) периодически устраивали выставки, на которых демонстрировали поделки, игрушки и пропагандировали идею необходимости повсеместного создания наглядных пособий для детских садов [НАРК. Ф. Р-148. Оп. 1. Д. 474. Л. 162].

В процессе осуществления «Дошкольного похода» удалось привлечь внимание широкой общественности к проблемам воспитания малолетних детей, это способствовало улучшению условий для создания новых и совершенствования работы действующих учреждений. Достаточно широко проводилась популяризация детских садов в прессе. Сугубо положительным явлением было совершенствование методики работы с дошкольниками и развитие методической помощи. Было организовано издание специализированной газеты «Дошкольный поход». Передовые работники проводили консультационную работу среди населения. Неоднократно в ходе реализации «Дошкольного похода» специалисты направлялись в сельскую местность для проведения курсов. Так, наиболее образованные и опытные педагоги г. Усть-Сысольска (Сыктывкара) оказали заметное влияние на улучшение деятельности детских садов и совершенствование методики работы с дошколятами в Визингском, Прилузском, Усть-Вымском, Удорском, Усть-Куломском, Сысольском районах [НАРК. Ф. Р-148. Оп. 1. Д. 474. Л. 137]. Безусловно, всецело были вовлечены в «Дошкольный поход» пионерские и комсомольские организации. Они проводили митинги и демонстрации, организовывали «агитационные повозки», лыжные пробеги, «живые газеты», выступления на радио. Кроме того, пионеры брали шефство над детскими площадками и садами [НАРК. Ф. Р-148. Оп. 1. Д. 474. Л. 133].

Следует отметить, что при организации «Дошкольного похода» в Коми автономной области сразу же выявились и различные недостатки. Так, профсоюзные и хозяйственные организации недооценивали, а нередко и игнорировали значение общественного дошкольного воспитания, что тормозило открытие новых детских учреждений. Далеко не везде и не в полной мере использовалась инициатива населения, или вообще отсутствовала широкая вовлеченность населения в развертывание «Дошкольного похода». В ходе выполнения планов по открытию детских садов обозначились проблемы изыскания необходимых средств и помещений, подготовки кадров, организации питания и медицинского обслуживания [НАРК. Ф. Р-148. Оп. 1. Д. 474. Л. 151]. Отсутствие квалифицированных специалистов не только обострило проблему нехватки педагогических кадров, но и актуализировало вопрос о едином подходе к эффективному руководству.

Несмотря на указанные проблемы, реализация «Дошкольного похода» в России, в том числе и в Автономной области Коми (Зырян), способствовала масштабным изменениям в системе воспитания малолетних детей; привела к более активному вовлечению женщин-работниц в общественную и производственную жизнь страны [НАРК. Ф. Р-148. Оп. 1. Д. 474. Л. 74]. Решая государственные задачи, специалисты ОБОНО Коми области предприняли ряд мер. Совершенствованию деятельности дошкольных заведений способствовала организация планового распределения бюджетных средств. В автономии началась подготовка специалистов дошкольного дела. Важно, что осуществлялась оценка проведения «Дошкольного похода», анализировалась деятельность пионерских, комсомольских, профсоюзных и партийных организаций. Такая работа закладывала основы и намечала перспективы эффективной работы по открытию новых дошкольных учреждений и совершенствованию их деятельности в Коми автономии, так как ко времени завершения «Дошкольного похода» в регионе только $6,6 \%$ детей до семи лет посещали детские сады и ясли [НАРК. Ф. Р-148. Оп. 1. Д. 474. Л. 74].

«Дошкольный поход» - уникальное, пусть и кратковременное явление в советской истории. За короткое время удалось не только открыть значительное количество новых дошкольных учреждений в городах и сельской местности, но и побудить трудящихся пересмотреть свои взгляды на воспитание детей в новых реалиях. 


\section{ЛИТЕРАТУРА И ИСТОЧНИКИ}

Aфанасова E. Н. Создание и развитие системы дошкольных учреждений в 1920-х гг. В Якутской АССР // Гуманитарные исследования в Восточной Сибири и на Дальнем Востоке. 2016. № 3 (37). C. 62-69.

Афанасова E. Н. Формирование кадрового состава дошкольных учреждений Восточной Сибири в 1920-1930-х гг. // Вестник Томского государственного университета. 2016. № 413. С. 64-69.

Бабинцева Т. В. История развития дошкольного воспитания в Вятском крае с 1866 по 1945 год // Вятские записки. Киров, 2011. Вып. 20. С. 112-132.

Васильева О. И., Воронщов В. С. «...Как свет для горного растения»: Кузебай Герд о значении и задачах дошкольного воспитания удмуртских детей // Ежегодник финно-угорских исследований. 2019 Т. 13. Вып. 2. С. 270-285.

Глущенко И. В. Советский просветительский проект: ликвидация неграмотности среди взрослых в 1920-1930-е годы // Вопросы образования. 2015. № 3. С. 246-282.

Город Сыктывкар. Энциклопедия. Сыктывкар, 2010. 408 с.

Егоров С. Ф., Лыков С. В., Волобуева Л. М. Введение в историю дошкольной педагогики. М.: Издательский центр «Академия», 2001. 320 с.

История Коми АССР с древнейших времен до наших дней. Издание второе, дополненное. Сыктывкар: Коми книжное издательство, 1981. 480 с.

История Коми с древнейших времен до современности. В двух томах. 2-е изд., испр. и доп. Сыктывкар: Анбур, 2011. Т. 2. 688 с.

Котов П. П., Пилипенко В. А. Деятельность органов по охране материнства и младенчества в Коми АССР в 1920 - 1930-х годах // Двинская земля. Материалы 6 межрегиональных общественно-научных историко-краеведческих Стефановских чтений. Котлас, 2010. С. 173-181.

Котов П. П., Пилипенко В. А. Здравоохранение в Коми АССР в 1920-1930-х годах: становление и развитие. Сыктывкар, 2011. $196 \mathrm{c}$.

Крупская Н. К. Педагогические сочинения: в 10 т. М.: Педагогика, 1959.

Луначарский А. В. О дошкольном походе // Народное просвещение. 1929. № 7. С.10-13.

Луначарский А. В., Скрыпник Н. А. Народное образование в СССР в связи с реконструкцией народного хозяйства: Доклады на VII съезде Союза работников просвещения. М.: Работник просвещения, 1929. $167 \mathrm{c}$.

Мартынчук T. А. Специфика организации общественного дошкольного воспитания в Коми АССР в 1930-е гг. // Финно-угорский мир. Международный научный журнал. 2013. № 3. С. 43-49.

Национальный архив Республики Коми (НАРК). Ф. Р-148. Оп. 1. Д. 212.

НАРК. Ф. Р-148. Оп. 1. Д. 474.

НАРК. Ф. Р-148. ОП. 1. Д. 562.

НАРК. Ф. Р-148. Оп. 1. Д. 672.

НАРК. Ф. 1538. Оп. 1. Д. 1.

Республика Коми. Энциклопедия. Сыктывкар: Коми книжное издательство, 1997. Т. 1. 472 с.; 1999. T. 2.576 c.; 2000. T. 3.400 c.

Поступила в редакцию 21.12.2020

Котов Петр Павлович,

кандидат исторических наук, доцент, Институт языка, литературы и истории ФИЦ «Коми НЦ УрО РАН» 167001 г. Сыктывкар, ул. Коммунистическая, 26 e-mail: kotoff.petr2018@yandex.ru;

Мартынчук Татьяна Александровна, заместитель директора Сыктывкарского гуманитарно-педагогического колледжа имени И. А. Куратова, 167001 г. Сыктывкар, Октябрьский проспект, 24 e-mail: martynchukt@mail.ru 


\title{
P. P. Kotov, T. A. Martynchuk \\ PRESCHOOL CAMPAIGN AS AN ELEMENT OF CULTURAL AND EDUCATIONAL CAMPAIGN OF THE LATE 1920S - EARLY 1930S: BASED ON THE MATERIALS OF THE KOMI-ZYRYAN AUTONOMOUS OBLAST
}

\author{
DOI: $10.35634 / 2224-9443-2021-15-1-147-156$
}

The paper discusses the features of the phenomenon of "Preschool campaign" as part of the cultural revolution in Soviet Russia. General trends in the development of preschool education in Soviet Russia are described. The main attention is paid to the peculiarities of the "Preschool campaign" in the Komi-Zyryan Autonomous Oblast. The problems of formation and development of the preschool system, their financing, material resources forming, training, organization of food, medical care and improving the methodology of working with preschoolers are analyzed. The authors point to ways to attract the population to the problems of public preschool education. It was revealed that the implementation of the "Preschool campaign" was accompanied by measures to promote a new, Marxist-Leninist ideology. The ideological component has become a mandatory component of all measures to expand the system of pre-school institutions and develop methods of pre-school education. The researchers believe that the implementation of the "Preschool campaign" in the Komi autonomy, even if various shortcomings were identified, contributed to large-scale changes in the system of upbringing of young children, and the activation of women workers in the social and production life of the region. It was identified that pioneer, Komsomol, Trade Union and party organizations played an important role in conducting the "Preschool campaign". The authors note the development of methods of working with preschoolers as a positive phenomenon. The improvement of methodological assistance consisted not only in practical assistance to teachers, but also in showing the best experience through the press. It is shown that in order to overcome the shortage of professional staff for preschool institutions in the Komi region, they went beyond the existing short-term pedagogical courses and sometimes attracted casual workers. In 1931, a pre-school Department of the Syktyvkar Pedagogical College was opened. During the "Preschool campaign" in the Komi-Zyryan Autonomous Oblast, it was possible not only to open a significant number of new pre-school institutions, to diversify the measures of pre-school education in towns and rural areas, but also to force population to reconsider it views on raising children.

Keywords: Cultural revolution, illiteracy elimination, preschool education, Preschool campaign, kindergartens, playgrounds, Komi-Zyryan Autonomous Oblast.

Citation: Yearbook of Finno-Ugric Studies, 2021, vol. 15, issue 1, pp. 147-156. In Russian.

\section{REFERENCES}

Afanasova E. N. Sozdanie i razvitie sistemy doshkol'nyh uchrezhdenij v 1920-h gg. V Jakutskoj ASSR [Establishment and development of preschool system in Yakut ASSR in the 1920s.]. Gumanitarnye issledovanija v Vostochnoj Sibiri i na Dal'nem Vostoke [Humanities research in the Russian Far East]. 2016. No. 3 (37), pp. 62-69. In Russian.

Afanasova E. N. Formirovanie kadrovogo sostava doshkol'nyh uchrezhdenij Vostochnoj Sibiri v 1920-1930-h gg. [The formation of the personnel of preschool institutions in Eastern Siberia in the 1920S 1930S.]. Vestnik Tomskogo gosudarstvennogo universiteta [Tomsk State University Journal], 2016. No. 413. Pp. 64-69. In Russian. DOI: 10.17223/15617793/413/10

Babintseva T. V. Istorija razvitija doshkol'nogo vospitanija v Vjatskom krae s 1866 po 1945 god [The history of preschool education development in Vyatka territory from 1866 to 1945]. Vjatskie zapiski [Vyatka notes]. Kirov, 2011. Issue 20. Pp. 112-132. In Russian.

Vasilyeva O. I., Vorontsov V. S. «...Kak svet dlja gornogo rastenija»: Kuzebaj Gerd o znachenii i zadachah doshkol'nogo vospitanija udmurtskih detej [“...As a light for mountain plants”: Kuzebay Gerd on the meaning and problems of preschool education of Udmurt children]. Ezhegodnik finno-ugorskikh issledovanii [Yearbook of FinnoUgric Studies]. 2019. Vol. 13. Issue 2. Pp. 270-285. In Russian. DOI: 10.35634/2224-9443-2019-13-2-258-273.

Glushchenko I. V. Sovetskij prosvetitel'skij proekt: likvidaciya negramotnosti sredi vzroslyh v 1920-1930-e gody [Soviet educational project: elimination of illiteracy among adults in the 1920s-1930s.]. Voprosy obrazovanija [Education issues]. 2015. No. 3. Pp. 246-282. In Russian.

Gorod Syktyvkar. Enciklopedija [The City of Syktyvkar. Encyclopedia]. Syktyvkar, 2010. 408 p. In Russian.

Egorov S. F., Lykov S. V. and Volobueva L. M. Vvedenie v istoriju doshkol'noj pedagogiki [Introduction to the history of preschool pedagogics]. Moskva: Izdatel'skij centr «Akademija», 2001. 320 p. In Russian. 
Istorija Komi ASSR s drevnejshih vremen do nashih dnej. Izdanie vtoroe, dopolnennoe [The history of the Komi ASSR from ancient times to the present day. 2nd edition, updated]. Syktyvkar, Komi Publ., 1981. 480 p. In Russian.

Istorija Komi s drevnejshih vremen do sovremennosti. $V$ dvuh tomah. 2-e izd., ispr. i dop. [The history of Komi from ancient times to the present. In 2 volumes. 2nd edition, revised and updated]. Syktyvkar, Anbur Publ., 2011. Vol. 2. 688 p. In Russian.

Kotov P. P., Pilipenko V. A. Dejatel'nost' organov po ohrane materinstva i mladenchestva v Komi ASSR v 1920 - 1930-h godah [Activity of Bodies for the protection of motherhood and infancy in the Komi ASSR in the 1920-1930s]. Dvinskaja zemlja. Materialy 6 mezhregional'nyh obshhestvenno-nauchnyh istorikokraevedcheskih Stefanovskih chtenij [Dvina land. Materials of six interregional social-scientific historical-local lore Stefan readings]. Kotlas, 2010. Pp. 173-181. In Russian.

Kotov P. P., Pilipenko V. A. Zdravoohranenie v Komi ASSR v 1920 - 1930-h godah: stanovlenie i razvitie. [Health care in the Komi ASSR in the 1920s-1930s: formation and development]. Syktyvkar, 2011. 196 p. In Russian.

Krupskaya N. K. Pedagogicheskie sochineniya: $v 10 t$. [Pedagogical readings: in 10 volumes]. Moskva, Pedagogika Publ., 1959. In Russian.

Lunacharskii A. V. O doshkol'nom pokhode [On the preschool campaign]. Narodnoe prosveshchenie [National enlightenment]. 1929. No. 7. Pp. 10-13. In Russian.

Lunacharskii A. V., Skrypnik N. A. Narodnoe obrazovanie v SSSR v svyazi s rekonstruktsiei narodnogo khozyaistva: Doklady na VII s"ezde Soyuza rabotnikov prosveshcheniya [National education in the USSR as a result of national economy reconstruction: $7^{\text {th }}$ congress of the Enlightenment workers Alliance reports]. Moskva, Rabotnik prosveshcheniya Publ., 1929. 167 p. In Russian.

Martyinchuk T. A. Specifika organizacii obshhestvennogo doshkol'nogo vospitanija v Komi ASSR v 1930-e gg. [Specific Features of Public Preschool Education in Komi ASSR in the1930s]. Finno-ugorskij mir. Mezhdunarodnyj nauchnyj zhurnal [The Finno-Ugric world. International scientific journal]. 2013. No. 3. Pp. 43-49.

Natsional'nyi arkhiv Respubliki Komi [National Archive of the Republic of Komi] (NARK). F. P-148. Op. 1. D. 212. In Russian.

NARK. F. P-148. Op. 1. D. 474. In Russian.

NARK. F. P-148. Op. 1. D. 562. In Russian.

NARK. F. P-148. Op. 1. D. 672. In Russian.

NARK. F. 1538. Op. 1. D. 1. In Russian.

Respublika Komi. Enciklopedija [The Republic of Komi. Encyclopedia]. Syktyvkar, Komi Publ., 1997, vol. 1.472 p.; 1999, vol. 2. 576 p.; 2000, vol. 3.400 p. In Russian.

Received 21.12.2020

Kotov Petr Pavlovich, Candidate of History Science, docent, Komi Science Centre, Ural Branch, Russian Academy of Sciences, Syktyvkar, Kommunisticheskaya st., 26, Syktyvkar, 167000, Russian Federation e-mail: kotoff.petr2018@yandex.ru;

Martynchuk Tatyana Aleksandrovna, Deputy Director

Syktyvkar humanitarian and pedagogical College named after I. A. Kuratov, Syktyvkar, Oktyabrskiy prospekt, 24, Syktyvkar, 167000, Russian Federation e-mail: martynchukt@mail.ru 